Release document

3. From: (Originating Organization)

Debris Removal, Project A2A

6. Design Authority/Design Agen//Cog. Engr.

11. Receiver Remarks:

11A. Design Baseline Document? [X] Yes [] No

\section{To: (Receiving Organization) \\ Debris Removal \\ 5. Proj./Prog./Dept./Div.: \\ SNF/Debris Removal A2A \\ 8. Originator Remarks:}

D. R. Precechtel

4. Related EDT No::

$$
\mathrm{N} / \mathrm{A}
$$

7. Purchase Order No.:

$\mathrm{N} / \mathrm{A}$

9. Equip/Component No.:

$\mathrm{N} / \mathrm{A}$

10. System/Bldy./Facility:

$105 \mathrm{~K} \mathrm{West}$

12. Major Assm. Dwg. No.:

$\mathrm{N} / \mathrm{A}$

13. Permit/Permit Application No.

N/A

14. Required Response Date:

\section{$12 / 01 / 99$}

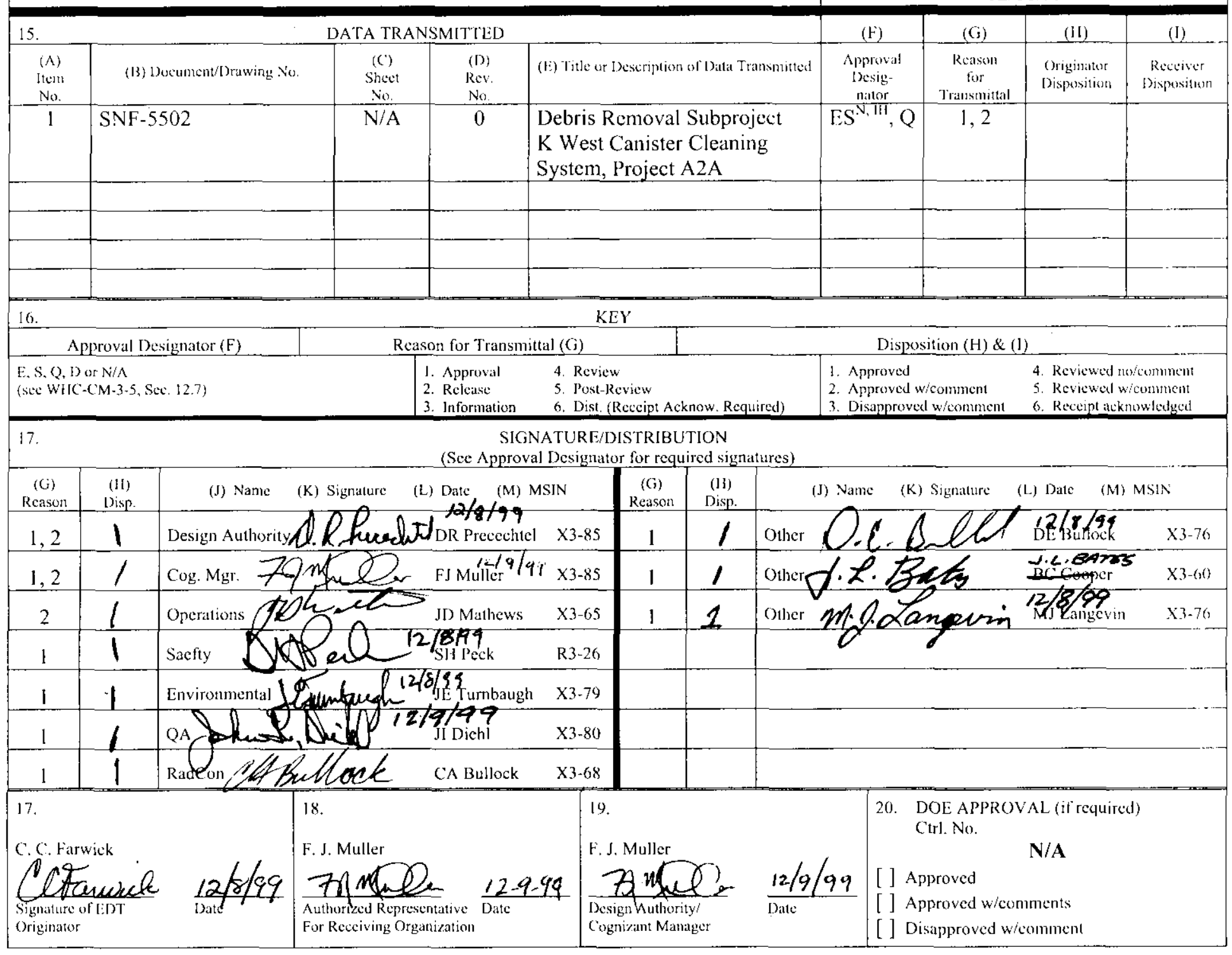




\title{
Debris Removal Project K West Canister Cleaning System Performance Specification
}

\author{
C. C. Farwick for \\ Fluor Daniel Hanford \\ Richland, WA 99352 \\ U.S. Department of Energy Contract DE-AC06-96RL13200 \\ $\begin{array}{llll}\text { EDT/ECN: } & 627340 & \text { UC: } & 2000 \\ \text { Org Code: } & 2 \mathrm{G} 400 & \text { Charge Code: } 105612 \\ \text { B\&R Code: } & \text { EW7040000 } & \text { Total Pages: } 29\end{array}$
}

Key Words: Design criteria, Canister Cleaning System, K West (KW), debris removal.

Abstract: Design criteria for a Canister Cleaning System to be installed in the KW Basin. This documents the requirements for design and installation of the system

TRADEMARK DISCLAIMER. Reference herein to any specific commercial product, process, or service by trade name, trademark, manufacturer, or otherwise, does not necessarily constitute or imply its endorsement, recommendation, or favoring by the United States Government or any agency thereof or its contractors or subcontractors.

Printed in the United States of America. To obtain copies of this document, contact: Document Control Services, P.O. Box 950, Mailstop H6-08, Richland WA 99352, Phone (509) 372-2420; Fax (509) 376-4989.
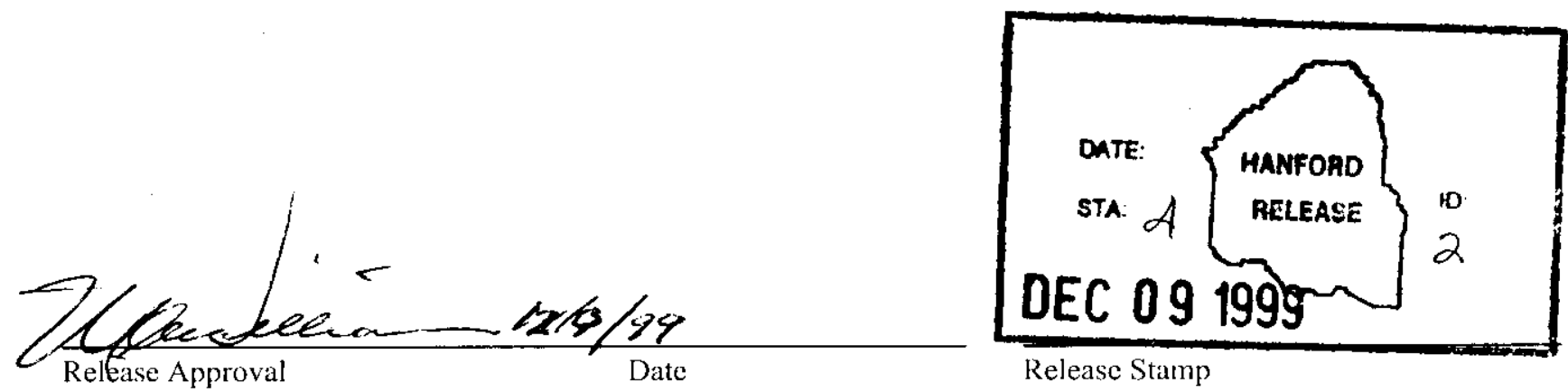


\section{SNF-5502 \\ REVISION 0 \\ PROJECT A.2.A}

\section{DEBRIS REMOVAL PROJECT}

K WEST CANISTER CLEANING SYSTEM PERFORMANCE SPECIFICATION

CONSISTING OF 24 PAGES

INCLUDING THIS COVER PAGE 


\section{TABLE OF CONTENTS}

1.0 SCOPE .1

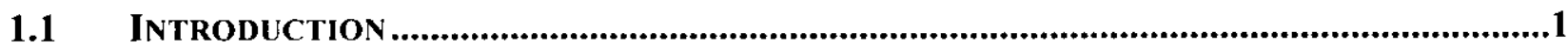

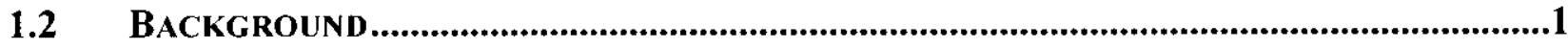

1.3 CANISTER Cleaning SUb-PROJECT...................................................................................1

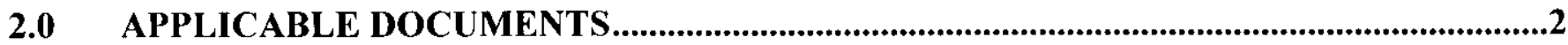

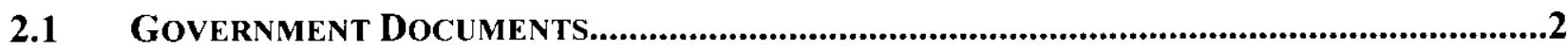

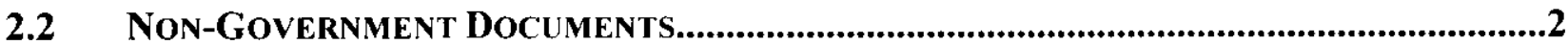

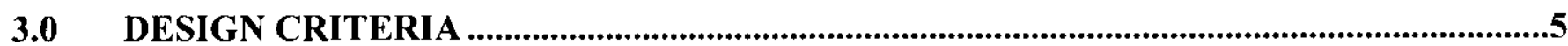

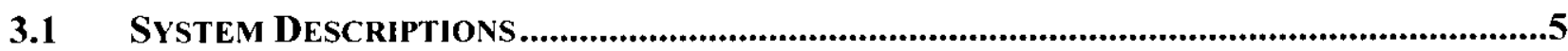

3.1.1 Canister Transport Subsystem ………....................................................................5

3.1.2 Canister Cleaning Subsystem ....................................................................................5

3.1.3 Canister Removal Subsystem....................................................................................5

3.1.4 Canister preparation section...............................................................................5

3.1.5 Canister Disposal Subsystem ................................................................................6

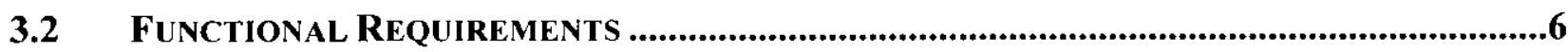

3.2.1 Canister Transport Subsystem Requirements .......................................................6

3.2.2 Canister Cleaning Subsystem Requirements .........................................................6

3.2.3 Canister Removal Subsystem Requirements.............................................................7

3.2.4 Canister Preparation Subsystem Requirement......................................................7

3.2.5 Canister Disposal Subsystem Requirements .........................................................7

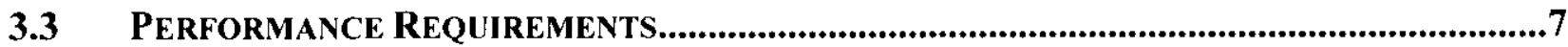

3.3.1 Canister Transport Subsystem Requirements .......................................................8

3.3.2 Canister Cleaning Subsystem Requirements ........................................................8

3.3.3 Canister Removal Subsystem Requirements............................................................8

3.3.4 Canister Preparation Subsystem Requirements ......................................................9

3.3.5 Canister Disposal Subsystem Requirements ...........................................................9

3.4 COMPONENT DESIGN REQUIREMENTS ............................................................................9

3.4.1 Instrumentation and Controls .....................................................................................9

3.4.2 Piping and Vessels Design Criteria ........................................................................9 
3.4.3 Mechanical Process design criteria …….................................................................10

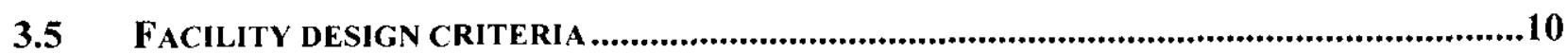

3.5.1 Architectural and Civil/Structural......................................................................10

3.5.2 Heating and Ventilation .........................................................................................11

3.5.3 Utilities ……..........................................................................................................11

3.5.4 Electrical .........................................................................................................11

3.5.5 Lighting ..............................................................................................................

3.5.6 Communication Systems ……...........................................................................11

3.5.7 Automatic Data Processing …………………........................................................12

3.5.8 Energy Conservation .......................................................................................12

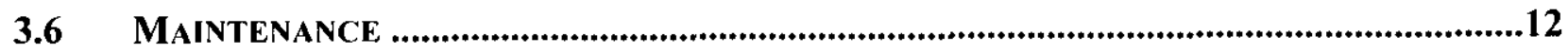

3.6.1 Facility Environment .......................................................................................12

3.6.2 Equipment ……..................................................................................................12

3.6.3 Replacement Parts ................................................................................................12

3.6.4 Routine Maintenance................................................................................................13

3.6.5 Component Failure .............................................................................................13

3.6.6 Common Components …………...............................................................................13

3.6.7 Lubrications .............................................................................................................13

3.7 SAFETY REQUIREMENTS ..............................................................................................13

3.7.1 Criticality ...........................................................................................................14

3.7.2 Safety Analysis .......................................................................................14

3.7.3 Radiological Controls ...........................................................................................14

3.7.4 Shielding ...........................................................................................................14

3.7.5 Industrial Safety ...............................................................................................14

3.7.6 Fire Protection.......................................................................................................15

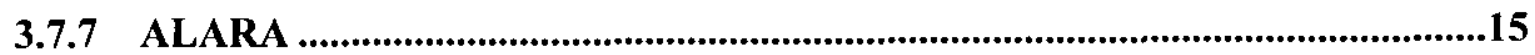

3.8 EnVIRonMENTAL PRoteCtion AND COMPLIANCE.........................................................15

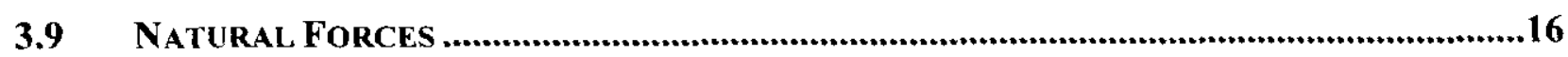

3.10 CANISTER CHARACTERISTICS ....................................................................................16

3.11 PREPARATION FOR DELIVERY ..........................................................................17

4.0 QUALITY ASSURANCE REQUIREMENTS ..................................................................18 
SNF- -5502Rev. 0

Project A.2.A

5.0 VALIDATION/VERIFICATION ....................................................................................

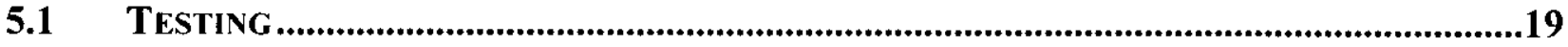

5.2 QUALIFICATION (VERIFICATION) .............................................................................19

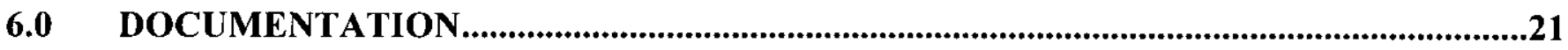

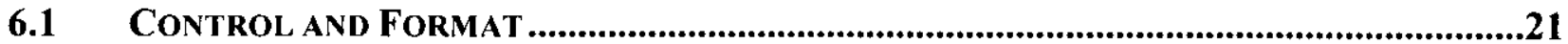

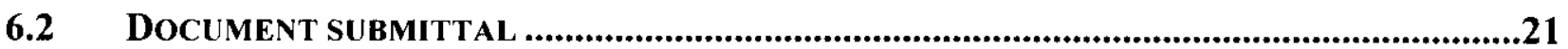

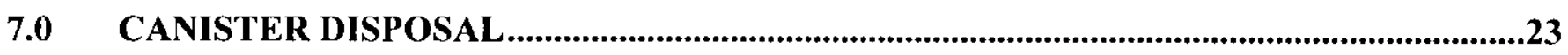

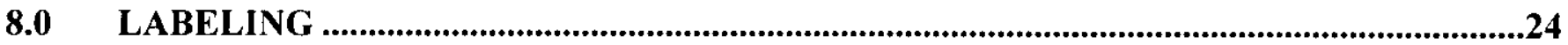

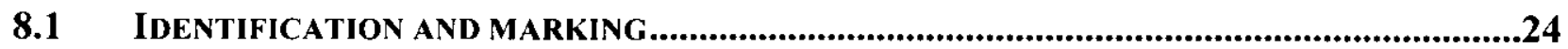

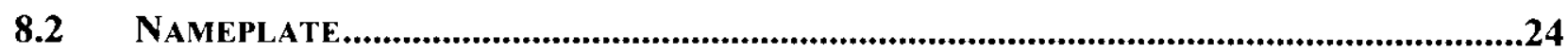




\subsection{SCOPE}

This section will provide an introduction, background information on the SNF project, and will define the scope of the document.

\section{$1.1 \quad$ INTRODUCTION}

Approximately 2,300 metric tons Spent Nuclear Fuel (SNF) are currently stored within two water filled pools, the $105 \mathrm{~K}$ East $(\mathrm{KE})$ fuel storage basin and the $105 \mathrm{~K}$ West $(\mathrm{KW})$ fuel storage basin, at the U.S. Department of Energy, Richland Operations Office (RL). The SNF Project is responsible for operation of the K Basins and for the materials within them. A subproject to the SNF Project is the Debris Removal Subproject, which is responsible for removal of empty canisters and lids from the basins.

\subsection{BACKGROUND}

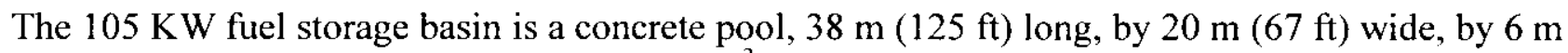
(21 ft) deep, containing approximately $4500 \mathrm{~m}^{3}$ (1,000,000 gal) of water, irradiated fuel, sludge, and debris (canister).

The KW fuel storage basin was constructed in the 1950s to receive and provide temporary storage for irradiated fuel from the $105 \mathrm{KW}$ production reactor. The reactor ceased operation in the early 1970s and the basin was taken out of service upon shipping the irradiated fuel to the 200 East Area for processing. During the mid-1970s, the KW Basin was modified to receive and temporarily store N Reactor fuel until it could be processed.

In the KW basin, SNF is stored in approximately 3700 closed top canisters. The SNF stored in the KW Basin has a maximum enrichment of 1.25 percent. The SNF Project is moving the SNF from the basin to the Cold Vacuum Drying Facility to condition it for long term storage. The Fuel Removal System (FRS) retrieves a canister from the cooling pool storage rack, brings it to the FRS where the canister lid is removed, fuel is separated from the canister and the canister returned to a storage rack location. The lids are accumulated in a container within the FRS. The Canister Cleaning System (CCS) will retrieve the empty canisters and lids and take them to the CCS for processing out of the basin.

\subsection{CANISTER CLEANING SUB-PROJECT}

The scope of the KW CCS is to design, procure, install and test the KW CCS. The project includes all modifications generated by the lessons learned on the design and operation of the existing system and equipment -in the K East Basin to install and operate the KW CCS in the KW Basin. The design of the $\mathrm{KW}$ CCS will provide a system in the $100 \mathrm{KW}$ Basin to retrieve, stage, clean, remove empty fuel canister and lids from the storage pool, prepare for transportation, and transport to final disposition. 


\subsection{APPLICABLE DOCUMENTS}

Applicable requirements (latest edition/revision) in the following government document, industry standards, and Hanford-specific documents shall be included in the design and fabrication of the KW CCS. Any exceptions shall be justified by the project and exceptions to government documents shall be approved by RL. This specification reflects the requirements as outlined in the SNF S/RIDs and HNF-PROs.

\subsection{GOVERNMENT DOCUMENTS}

10 CFR 830, Nuclear Safety Management, Code of Federal Regulations.

10 CFR 835, Occupational Radiation Protection, Code of Federal Regulations.

29 CFR 1926, Safety and Health Regulations for Construction, Code of Federal Regulations.

DOE 435.1, Radioactive Waste Management, U.S. Department of Energy, Washington, D.C.

DOE 5400.5, Radiation Protection of the Public and the Environment, U.S. Department of Energy, Washington, D.C.

DOE Order 5480.24, Nuclear Criticality Safety, U.S. Department of Energy, Washington, D.C

DOE Order 6430.1A, General Design Criteria, U.S. Department of Energy, Washington, D.C.

WAC 296-104, Board of Boiler Rules, Substantive, Department of Labor and Industries, Olympia, Washington.

\subsection{NON-GOVERNMENT DOCUMENTS}

0000X-DC-W0001, Rev 1, Supplemental Waste Acceptance Criteria for Bulk Shipments to the Environmental Restoration Disposal Facility

ANSI/ASME NQA-1, Quality Assurance Program Requirements for Nuclear Facilities

ANSI/AWS, Structural Welding Code - Steel, ANSI/AWS D1.1, American National Standards Institute and American Welding Society, Miami, Florida.

ANSI/ISA, Annunciator Sequences and Specifications, S18.1, Instrument Society of America, Research Triangle Park, North Carolina.

ANSI/ISA, Safety Standard for Electrical and Electronic Test, Measuring, Controlling and Related Equipment - General Requirements, S82.01, Instrument Society of America, Research Triangle Park, North Carolina. 
ANSI/ISA, Safety Standard for Electrical and Electronic Test, Measuring, Controlling and Related Equipment - Electrical and Electronic Process Measurement and Control Equipment, S82.03, Instrument Society of America, Research Triangle Park, North Carolina.

AP EN-6-005, Engineering Component Identifier and Labeling Control, Fluor Daniel Hanford, Richland, Washington.

AP EN-6-030, Rev 1, Engineering Process, Fluor Daniel Hanford, Richland Washington

AP RP-12-005, ALARA Training, Fluor Daniel Hanford, Richland Washington

AP RP-12-009, Radiological Review Process, Fluor Daniel Hanford, Richland Washington

ASME B31.1, Power Piping, American Society of Mechanical Engineers, New York, New York.

ASME Section VIII, Boiler and Pressure Vessel Code, Rules for Construction of Pressure Vessels, American Society of Mechanical Engineers, 1995, New York, New York.

BHI-00139 Rev 3, Environmental Restoration Disposal Facility Waste Acceptance Criteria HNF-3552, Rev 0, SNF Project Execution Plan, Fluor Daniel Hanford, Richland Washington

HNF-MP-599, Project Hanford Quality Assurance Program Description, Fluor Daniel Hanford, Richland, Washington.

HNF-PRO-097, Engineering Design and Evaluation, Fluor Daniel Hanford, Richland, Washington.

HNF-PRO-1620, ALARA Program Scope, Fluor Daniel Hanford, Richland Washington.

HNF-PRO-1621, ALARA Decision Making Methods, Fluor Daniel Hanford, Richland Washington.

HNF-PRO-1622, Radiological Design Review Process, Fluor Daniel Hanford Company, Richland, Washington.

HNF-PRO-1633, ALARA Program Records, Fluor Daniel Hanford, Richland Washington.

HNF-PRO-1819, PHMC Engineering Requirements, Fluor Daniel Hanford, Richland, Washington.

HNF-PRO-259, Graded Quality Assurance, Fluor Daniel Hanford, Richland Washington

HNF-PRO-517, Safety Analysis Program Glossary, Fluor Daniel Hanford, Richland, Washington.

HNF-PRO-704, Hazard and Accident Analysis Process, Fluor Daniel Hanford, Richland, Washington.

HNF-PRO-709, Preparation and Control Standards for Engineering Drawings, Fluor Daniel Hanford, Richland, Washington. 
SNF- -5502Rev. 0

Project A.2.A

HNF-SD-SNF-FHA-001, Fire Hazards Analysis for the K Basins Facility at the $100 \mathrm{~K}$ Area, Fluor Daniel Hanford, Richland, Washington.

HNF-SD-SNF-TI-015, SNF Project Technical Data Book, Fluor Daniel Hanford, Richland Washington

HSRCM-1, Hanford Site Radiological Control Manual, Pacific Northwest Laboratory, Richland, Washington.

NFPA, National Electrical Code, ANSI/NFPA 70, National Fire Protection Association, Quincy, Ma.

UBC, Uniform Building Code, UBC-97, International Conference of Building Officials, Whittier, California.

WHC-SD-WM-SAR-062, Safety Analysis Irradiated N Reactor Fuel, Fluor Daniel Hanford, Richland, Washington. 


\subsection{DESIGN CRITERIA}

\subsection{SYSTEM DESCRIPTIONS}

The Canister Cleaning System shall be designed to "clean" empty fuel canisters and lids and package for disposal to ERDF complex. The system will interface with the K W Basin and be located in the Dummy Elevator Pit.

The canister cleaning system will be made up of the following subsystem:

Canister Transport Subsystem

Canister Cleaning Subsystem

Canister Removal Subsystem

Canister Preparation Subsystem

Canister Disposal Subsystem

\subsubsection{Canister Transport Subsystem}

The empty canisters shall be retrieved from the fuel cleaning station to the dummy elevator pit utilizing the existing monorail and trolley system.

\subsubsection{Canister Cleaning Subsystem}

The canister cleaning station shall be located in the dummy elevator pit, attached to the wall.

At the canister cleaning station the canisters and lids will be washed inside and out with high-pressure water jets. The purpose of the high-pressure water jet is to clean the canisters so that they can be disposed of as low level waste and buried at the ERDF complex. Canister cleaning will take place at least 8 feet below the surface of the water.

The cleaning will be done in two stages. The outside of the canister will be cleaned by multiple nozzles while the inside is cleaned by an array of fixed nozzles as the canister is moved through the station. The cleaning process will be performed by automatically moving the canisters through the cleaning station.

\subsubsection{Canister Removal Subsystem}

Once the canisters are cleaned they will be moved into a HEPA filtered containment enclosure where they will be removed from the basin water.

\subsubsection{Canister preparation section}

While in the containment enclosure the canisters and lids will be allowed to drip-dry. The containment enclosure will allow for radiological surveys, characterization, etc. 


\subsubsection{Canister Disposal Subsystem}

The canisters will be transported from the containment enclosure to the burial boxes by a pull cart, which can transport three to four canisters at a time.

\subsection{FUNCTIONAL REQUIREMENTS}

The general functional requirements are the requirements that apply to the total canister cleaning system. Each subsystem will have a set of specific functional requirements.

Systems provided by this project should use commercially available equipment and technologies.

The design shall implement the DOE requirements for Occupational Radiation Protection, Design and Control.

The systems provided shall minimize the impact on fuel, sludge, and debris removal operations by minimizing service interruptions during construction, testing and operation of the project.

The CCS shall provide equipment, components, tooling, and systems to clean and remove canisters and lids from the fuel storage pools.

The KW CCS function requirements are defined for each of the sub-systems.

\subsubsection{Canister Transport Subsystem Requirements}

The KW CCS shall have the capability to transfer canisters and lids from anywhere in the Basin to the Cleaning Station.

The existing basin systems (monorail, trolly, etc.) shall be utilized as much as possible.

$\mathrm{KW}$ shall provide capability to stage ten canisters and lids near cleaning station.

\subsubsection{Canister Cleaning Subsystem Requirements}

Canisters and lids shall be washed with pressurized water to dose limits below K-Basin Rad Con manual for high radiation area requirements.

Canisters and lids shall be washed to meet dose limits based on final packaging to ERDF acceptance criteria.

KW CCS shall provide capability to wash canisters that have been cut open with the FRS stuck fuel equipment.

Final rinse shall utilize demineralized water from the existing decontamination hose bib system. 


\subsubsection{Canister Removal Subsystem Requirements}

KW CCS shall provide a containment enclosure to ensure basin air environment is not affected and activity is bounded by the DOH air permit.

\subsubsection{Canister Preparation Subsystem Requirement}

The system shall be designed for removal of canisters and lids from the containment enclosure without having airborne contamination level exceeded Alpha 2 E-13 micro cu/ml and Beta $2 \mathrm{E}-10 \mathrm{micro} \mathrm{cu} / \mathrm{ml}$.

\subsubsection{Canister Disposal Subsystem Requirements}

The disposal subsystem shall provide a safe and effective method of transferring canisters from containment enclosure to burial container.

Final package of cleaned canisters and lids shall meet transportation requirements for weight and dose.

Final package of cleaned canisters and lids shall meet ERDF requirements.

Contamination levels on canisters and lids shall not exceed Basin Action Limits $\left(10,000 \mathrm{dpm} / 100 \mathrm{~cm}^{2}\right)$ when removed from the containment enclosure.

\subsection{PERFORMANCE REQUIREMENTS}

The general performance requirements are the requirements that apply to the total canister cleaning system. Each subsystem will have a set of specific design requirements.

The system shall have an operational life of 4 years.

The system shall be designed to facilitate decontamination and limit the accumulation of contamination.

Systems that will be located in the basin pool should be fabricated from stainless steel or coated with a coating that will facilitate decontamination.

Equipment to be placed over the grating shall not impose loads such that the combined grating loading shall not exceed $60 \mathrm{lbs} / \mathrm{ft} 2$. Concentrated loads, i.e., transport carts, will be received on a case-by-case basis and approved by $\mathrm{K}$ Basins Cognizant Engineering prior to installation.

The system shall be monitored by means of Basin supplied cameras and radiation detectors.

All welds shall be performed by a qualified welder using approved procedures per AWS D.1.1.

Weld inspections shall be performed per AWS D.1.1 for structural systems. ANSI B31.1 for piping on fabricated systems. 


\subsubsection{Canister Transport Subsystem Requirements}

The canister transport system shall use existing equipment.

\subsubsection{Canister Cleaning Subsystem Requirements}

The system shall be designed to clean the inside and outside of each canister. The system shall be capable of cleaning between the canisters and the bottom of the canisters.

The system shall have the capability to clean 20 canister lids per 24 -hour workday.

The canister cleaner shall be capable of cleaning ten canisters per 24-hour workday.

Canister cleaning equipment shall be capable of removing all freestanding sludge on the inner and outer surfaces of the canister.

The system shall be capable of repeating the cleaning cycle on a canister.

The system shall be designed to minimize equipment components required to be removed from the basin pool for maintenance activities.

Empty canisters shall be cleaned at least $8 \mathrm{ft}$. below the surface of the basin water to minimize water surface disturbance and operator dose.

The high-pressure water system shall have a bypass on the water supply or discharge. The bypass shall be capable of discharging at $8 \mathrm{ft}$. or $16 \mathrm{ft}$. below water surface into the basin.

The empty canisters shall be manually placed into the cradle of the cleaning system.

The water for the canister cleaning system shall be from the discharge from the IWTS. The discharge will provide $30 \mathrm{gpm}$ at 25 psig.

The High-pressure water system shall be designed with lockable isolation valves between the skid and the Ion Exchange Module discharge connection.

\subsubsection{Canister Removal Subsystem Requirements}

The containment system shall be designed to accommodate canister-cleaning equipment removed from the basin pool for maintenance activities.

Provisions shall be provided in the CCS design for ease of removal from the basin for any part of the cleaning equipment that requires maintenance.

All movement of canisters and lids to the containment shall be performed underwater to prevent the transport of contamination from the water to the basin air. 


\subsubsection{Canister Preparation Subsystem Requirements}

The system shall be designed to minimize any liquid not compatible with the basin water system from leaking into the basin.

Fixatives or other chemical compounds used to prepare the canisters for disposal shall be compatible with basin water in the fuel pool.

\subsubsection{Canister Disposal Subsystem Requirements}

Canister and lids shall be packaged to meet ERDF acceptance criteria.

\subsection{COMPONENT DESIGN REQUIREMENTS}

\subsubsection{Instrumentation and Controls}

Any alarms designed in the CCS shall interface with the KW Alarm Monitoring Systems.

Local instrumentation shall be provided for components requiring manual control to ensure normal operations, ease of trouble shooting and maintenance, and personnel safety.

System manual controls shall be located in a low dose area.

Human factor engineering principles should be incorporated into the design and layout of the system, including placement and location of visual indicators, calibration equipment, and maintenance access areas.

Selection of area radiation monitoring equipment shall be coordinated with other SNF Basin Projects (sludge removal, fuel removal) and approved by SNF Radiological Controls.

Selection of instrumentation and controls shall be reviewed by SNF Engineering to promote selection of common devices and reduce maintenance by and training of SNF personnel.

Instrument field contacts, if required, shall be powered by 24 VDC unless otherwise authorized by the project

The instrumentation design shall utilize off the shelf equipment as much as possible.

I\&C shall accommodate required calibrations and testing.

\subsubsection{Piping and Vessels Design Criteria}

Piping materials of construction and capacities shall be compatible with the $\mathrm{KW}$ Basin water solution relevant to their application. 
Piping and/or hose assembles shall be designed to ASME B31.1, Power Piping or an approved equivalent for the commercial equipment. The commercial equipment (High-pressure water system) system shall be hydrostatically tested in accordance with the requirements B31.1.

Piping and /or hose assemblies shall be designed/supported to meet seismic requirements of UBC-97.

New supports for piping and/or hose assemblies and/or hose runs shall be designed to support the addition of supplemental shielding, as determined by ALARA evaluation and normal and off-normal operations.

All lines shall be clearly marked/identified per AP-EN-6-005-02, Engineering Component Identifier and Labeling Control.

Piping/hose systems shall be designed for drainage back to the basin pool. Low points shall be minimized and have drains.

Materials used to fabricate pipes/hoses carrying contaminated materials shall be selected to minimize internal contamination build up and subsequent decontamination and deposal issues.

High points in the system shall have vents.

Piping corridor spacing shall be designed with consideration to inspections, maintenance, and emergency repair.

Pressure vessels shall meet the requirements of ASME Boiler and Pressure Vessel Codes, Section VIII, Rules for Construction of Pressure Vessels. Pressure vessel relief valve outlet shall extend to the basin.

Vessel materials of construction and capacities shall be compatible with the KW Basin water solutions relevant to their application.

\subsubsection{Mechanical Process design criteria}

KW Basin systems of monorail, hooks, and strong backs shall be utilized wherever possible. Any new systems associated with the KW CCS shall be compatible with the existing K Basin equipment.

Pumps and other mechanical equipment shall be designed to limit combined noise levels from the KW CCS to 85 decibels or less at 1 meter.

\subsection{FACILITY DESIGN CRITERIA}

\subsubsection{Architectural and Civil/Structural}

Design shall take into account building components loading capability to ensure construction and operation of equipment does not violate weight limits for grating, monorails, etc.

Equipment installation shall conform to and comply with the general safety and environmental requirements. 
Piping and electrical conduit trays/racks shall be routed to accommodate access for maintenance related items.

\subsubsection{Heating and Ventilation}

Air discharged from the containment into the basin air space is subject to the limitations on potential to emit identified in the KW NOC air permit.

Air discharged from the containment shall be HEPA filtered as required per HSRCM-1, Art.464.

\subsubsection{Utilities}

Utilities that are required to service new or modified CCS equipment shall be provided by this project. The capacity and quality of the electrical power supply shall consider all added instrumentation and equipment needs.

- Steam shall not be used for the CCS

- The CCS will not interface with the K Area Sanitary or process sewer tie-ins.

- The CCS will require access to de-mineralized water system for final rinse of canisters.

\subsubsection{Electrical}

Electrical capacity shall be provided by the KW Basin to handle average and peak loads

The commercial equipment electrical shall be UL listed.

The electrical system (not covered above) shall comply with NFPA 70 National Electrical Code. The design shall consider the requirements of DOE 6430.1 A General Design Criteria, Section 1600, and incorporate those that are appropriate to the temporary nature of the facility and the four-year project design life.

\subsubsection{Lighting}

Standard industrial lighting, appropriate to various areas, shall be employed. Lighting in areas that may become high or very high radiation areas shall have a long-life design and shall be designed to minimize dose required for change out. Underwater work shall be providing with lighting levels as required by the basin.

The design shall consider the requirements of DOE 6430,1 A General Design Criteria, Sections 0278 and 1655 , and incorporate theses that are appropriate to the temporary nature of the facility and the four year project design life.

\subsubsection{Communication Systems}

The existing communication system in the KW Basin shall be used for activities associated with CCS. 


\subsubsection{Automatic Data Processing}

There are no special ADP requirements.

\subsubsection{Energy Conservation}

Based on the temporary nature of the facility and the four-year design life of the project, energy conservation requirements are not considered appropriate to this activity.

\subsection{MAINTENANCE}

The design and material selection shall include features that facilitate maintenance of the equipment, 10 CFR 835.1002 (d). Particular attention shall be paid to pumps, valves, and any underwater equipment.

\subsubsection{Facility Environment}

The CCS under water equipment shall be designed to operate in the high radiation environment that will be experienced during normal handling operations. The minimum requirement for the $\mathrm{CCS}$ is the ability to withstand an integrated dose of $2 \times 10^{7}$ rad over the anticipated four years life of the CCS. Above water components shall be designed for operation in a $5 \mathrm{mrem} / \mathrm{hr}$ radiation field.

Selection of area radiation monitoring equipment shall be coordinated with other SNF Projects [i.e., debris (canister) removal, sludge removal, fuel removal] and approved by SNF Projects Radiological Controls.

The acquisition of environmental permits and conformance to those permits shall be the responsibility of SNF Projects. Conformance of design to those permits is the responsibility of both the design contract and SNF Project. Changes to the PTE (potential to emit) stated in the Radioactive Air Emissions Notice of Construction Fuel Removal for $105 \mathrm{KW}$ Basin (DOE/RL-96-101) shall be approved by the appropriate Washington State and Federal regulators.

\subsubsection{Equipment}

The CCS shall be designed to facilitate safe handling. Considerations should be given for in-place or inservice repair and preventative maintenance of equipment to minimize cost of disassembly and interruption of service.

\subsubsection{Replacement Parts}

The equipment shall be designed using standard off the shelf equipment/parts and minimize specialty equipment/parts. Any parts, materials or assemblies expected to degrade or wear during normal use or exposure shall be easily replaceable. 


\subsubsection{Routine Maintenance}

The CCS shall be designed to minimize the need for routine maintenance due to the short design life.

\subsubsection{Component Failure}

The failure of any system components shall not reduce the design life, damage other components reduce the capabilities of the CCS or any associated interface components. Components that may fail or wear out before the end of the project life shall be identified on a spare parts list with recommended stock and inventory included.

\subsubsection{Common Components}

To the maximum extent practicable, common components shall be used to minimize spare parts, tools, and procedures.

\subsubsection{Lubrications}

Components shall be permanently lubricated to the maximum extent possible. If lubrication is required, the equipment shall be designed to allow lubrication through the use of fittings and with out requiring the disassembly of any parts other than the simple removal of a protective cap or booting. The leakage of lubricants into the basin water shall be controlled either by engineered containment or be compatible with the ion exchange media. The impacts of leakage of any lubricant shall be included in the design and performance of the CCS.

Lubricants presently approved for use in fuel storage basin:

- Lubricant 630AA mixed with Molykote $77^{\mathrm{TM}}{ }^{1}$

- Never Seize ${ }^{\mathrm{TM}}{ }^{2}$ pure nickel lubricant.

- Molykote $77^{\mathrm{rM}}$

\subsection{SAFETY REQUIREMENTS}

The Canister Cleaning System's safety classification is general service. The Performance Category is 2 . The system will be installed in the KW Basin, a hazard Category 2 facility.

Lifting and rigging of equipment shall comply with Hanford Hoisting and Rigging Manual (DOE-RL-92-36).

\footnotetext{
${ }^{1}$ Molykote $77^{\mathrm{TM}}$ is a trademark of The Alpha Molykote Corporation, Stamford Connecticut Corporation, Connecticut

${ }^{2}$ Never Seize ${ }^{\mathrm{TM}}$ is a trademark of Bostik, Inc., Massachusetts 01949 Corporation, Delaware 


\subsubsection{Criticality}

The design of the CCS shall prevent a criticality event. Any sludge accumulation in the Dummy Elevator shall not exceed 4.9 inches per K Basin Process Standards 304.

\subsubsection{Safety Analysis}

Safety classification of systems components, and structures shall meet HNF-PRO-704, Hazards and Accident Analysis Process. The CCS is low hazard. The safety classification is General Service. The $\mathrm{K}$ Basins SAR shall be updated to include the KW CCS. All equipment/material movement in the $105 \mathrm{KW}$ shall follow procedures to protect the spent fuel.

\subsubsection{Radiological Controls}

Guidance provided in AP RP-12-009, Radiological Review Process, shall be considered.

The system shall be designed to minimize the spread of contamination and creation of a surface contamination area.

Air monitors shall be provided as required. Equipment selection and placement shall be approved by SNF Radiological Controls organization.

Area radiation monitors shall be provided as necessary. Equipment selection and placement shall be approved by SNF Radiological Controls organization.

\subsubsection{Shielding}

Shielding if required for the CCS shall be provided to reduce worker exposure to ALARA goals. AS an ALARA goal no worker will receive greater than 1 person-Rem for equipment operation. Shielding if added shall be documented on drawings.

Radiological engineering calculations to define specific shielding needs shall be made during the design process.

Guidance provided in AP RP-12-009, Radiological Review Process, shall be considered.

\subsubsection{Industrial Safety}

Engineered controls shall be used first, only when engineered controls are not possible should administrative controls be used. Administrative controls, if engineered controls are not in place, shall be in place to protect from potential radionuclide releases during installation of equipment.

Existing work procedures shall be implemented to ensure the safety of the construction and operating personnel in and around the area of the KW Facility.

State and federal safety and health regulations, 29 CFR 1926, shall be followed during all construction phases of the project. 


\subsubsection{Fire Protection}

Fire protection requirements for the $\mathrm{CCS}$ will be defined during the design process through a fire hazards analysis and will be documented in a revision to the Fire Hazards Analysis For the K Basins Facility at the $100 \mathrm{~K}$ Area, HNF-SD-SNF-FHA-001.

\subsubsection{ALARA}

ALARA concepts shall be incorporated into all aspects of this cleaning system design.

The applicable requirements of the following documents shall be met:

1. 10 CFR 835, Occupational Radiation Protection

2. HSRCM-1, Hanford Site Radiological Control Manual

3. DOE $6430.1 \mathrm{~A}$, General Design Criteria

4. HNF-PRO-1620, ALARA Program Scope

5. DOE 5400.5, Radiation Protection of the Public and the Environment

6. DOE Order 435.1, Radioactive Waste Management

7. AP-RP-12-009 Radiological Review Process

8. HNF-PRO-1621, ALARA Decision Making Methods

9. AP RP-12-005, ALARA Training

Cost benefit analysis shall use the monetary value of 1 rem of collective dose is equivalent to $\$ 30,000$.

All actions and decisions taken to maintain occupational exposure ALARA shall be documented [10 CFR 835.704(b)].

\subsection{ENVIRONMENTAL PROTECTION AND COMPLIANCE}

A Radioactive Air Emissions Notice of Construction Fuel Removal for $105 \mathrm{KW}$ Basin (DOE/RL-96-101) was issued in April 1997. A page change was issued in December 1997. The CCS should be designed to meet the intent of the NOC. Any modifications to the NOC will be the responsibility of FDH Canister Cleaning Subproject. 


\subsection{NATURAL FORCES}

The anchorage of structures, systems, and components shall be designed in accordance with HNF-PRO-097, Engineering Design and Evaluation. All equipment located outside the basin shall be designed with weather protection based on local weather conditions.

\subsection{CANISTER CHARACTERISTICS}

The canister and lid reference drawings are as follows:

H-1-42594, Modified Mark I Canister

H-1-42793, Mark I Canister

H-1-42836, Canister Seal Assembly

H-1-46215, Mark II Canister

The system shall clean empty canisters from $\mathrm{KW}$ with the distribution defined in the following table.

Table 3-1. Empty Canisters distribution in the KW

\begin{tabular}{|l|c|c|c|c|}
\hline \multicolumn{1}{|c|}{ Canister } & East Bay & Center Bay & West Bay & Total \\
\hline \hline Mark I Al & $315(8 \%)$ & $22(1 \%)$ & $443(11 \%)$ & $780(20 \%)$ \\
\hline Mark I SS & $181(5 \%)$ & $777(20 \%)$ & $0(0 \%)$ & $958(25 \%)$ \\
\hline Mark II SS & $1032(27 \%)$ & $919(24 \%)$ & $153(4 \%)$ & $2104(55 \%)$ \\
\hline Total & $1528(40 \%)$ & $1718(45 \%)$ & $596(15 \%)$ & $3842(100 \%)$ \\
\hline
\end{tabular}

Note: Percentage in the last column is new survey released in AL Pitner Memo.

The system shall clean empty canister with the characteristics defined in Table 3-2.

Table 3-2. Empty Canisters Characteristics*

\begin{tabular}{|l|c|c|c|}
\hline Empty Canister Name & Diameter & Length & Total Weight \\
\hline \hline Mark I Al & $18.0 \mathrm{in}$. & $28.0 \mathrm{in}$. & $12-19 \mathrm{lbs}$. \\
& $(457.2 \mathrm{~mm})$ & $(711.2 \mathrm{~mm})$ & $(5.4-8.6 \mathrm{~kg})$ \\
\hline Mark I SS & $18.0 \mathrm{in}$. & $28.0 \mathrm{in}$. & $35 \mathrm{lbs}$. \\
& $(457.2 \mathrm{~mm})$ & $(711.2 \mathrm{~mm})$ & $(15.9 \mathrm{~kg})$ \\
\hline Mark II SS & $18.37 \mathrm{in}$. & $29.05 \mathrm{in}$. & $47 \mathrm{lbs}$. \\
& $(466.60 \mathrm{~mm})$ & $(737.87 \mathrm{~mm})$ & $(21.3 \mathrm{~kg})$ \\
\hline
\end{tabular}

*The numbers need to be verified 


\subsection{PREPARATION FOR DELIVERY}

General requirements for preservation, packaging, and package marking are specified in the following paragraphs. Any special unpacking and/or disassembly instructions required to receive the shipment shall be included in the Seller's packaging/shipping procedures.

- Items shall be protected from dirt, soil, and moisture, and be suitable for unprotected storage outside.

- $\quad$ Piping shall be plugged, capped, or blanked before shipment.

- Items shall be packaged in a manner to prevent damage or contamination during shipping.

Piping shall be shipped in equal lots of 20 and 40 foot lengths

- Packages shall be suitably marked on the outside to facilitate identification of the purchase order, the procurement specification, the package contents, and any special handling instructions.

- Equipment needs to be lubricated in accordance with operating and maintenance instruction manuals prior to installation and testing.

- Equipment and materials will be boxed or crated in a manner to prevent damage during shipment. Suitable packing material and dunnage will be included inside of boxes and crates to prevent equipment from shifting around inside of boxes and crates. Boxes and crates will be securely fastened down during shipping.

- Photos should be taken of materials in crates and boxes prior to sealing to document equipment condition and proper packaging. Additional photos should be taken of boxes and crates once they are strapped down on truck, if possible.

- SNF Buyer's personnel will be notified when material is shipped on site. 


\subsection{QUALITY ASSURANCE REQUIREMENTS}

The Contractor involved in the design, procurement, fabrication, or construction of the Canister Cleaning System shall have a documented Quality Assurance (QA) program meeting the requirements of HNF-MP-599, Rev 3 Project Hanford Quality Assurance Program Description, Part 2, Section 1-10, subsections 3, which is the Hanford Site implementation document for 10 CFR 830.120 Quality Assurance Requirements. The Contractor's QA Program shall have provisions to pass the applicable requirements on to subcontractors.

Implementation of these requirements will provide the following assurances:

1. Design data and design decisions are documented and traceable.

2. The design and design criteria are adequately supported by the prepared plans, specifications, and analysis.

3. Design inputs are identified

4. Design verification is performed to assure adequacy of design, the quality of construction and manufactured components, operability and maintainability, and reliability.

The CCS is a general service, Quality Level 3 procurement as described in HNF-PRO-259, Revision 0, Graded Quality Assurance. The Project has determined that the items, services and process have no engineering safety function by still require additional controls beyond commercial practices. The Quality level 3 designation shall provide the additional QA to provide a product that was design and procured to these specifications.

QA shall perform receipt inspection on all equipment shipped to KW Basin. 


\subsection{VALIDATION/VERIFICATION}

\subsection{TESTING}

Testing shall be performed to validate system functions as designed.

Items shall be inspected for cleanliness before acceptance testing, and prior to packaging for shipment. Dirt, oil residue, liquids, metal chips, or other forms of contamination shall be removed using the Seller's approved cleaning methods. A procedure shall be submitted for approval for on the cleaning methods used by the fabricator. The cleanliness inspection documentation shall be generated and transmitted to the Buyer

Factory Acceptance testing shall be performed by the fabricator of equipment prior to shipment to the Contractors facility. Test procedures shall be reviewed and approved prior to testing at the factory.

Validation Acceptance Testing shall be preformed at the contractor's facility prior to shipment to the $\mathrm{KW}$ Basin. Test procedures shall be reviewed and approved prior to testing at the factory.

Acceptance Testing shall be performed by project personnel in the basins to validate the system has been installed correctly and all systems work. The ATPs shall be reviewed and approved, as a minimum, by operations, Design Authority, Radiological Controls and the Project Manager.

The project manager and the receiving operation organization will determine additional testing/operations training.

Test reports for the FAT and ATP shall be issued through the Hanford Site document control and contain the test procedures, test results, and any recommendation for modification of the system.

\subsection{QUALIFICATION (VERIFICATION)}

Design verification will be by formal Design Review, which shall be performed and documented per HNF-PRO-1819, PHMC Engineering Requirements. The frequency of the design reviews (i.e. $60 \%$, and $90 \%$ ) shall be developed and proposed in the work plan by the Contractor.

The Contractor will participate in the Design Review kickoff meeting where the design media will be presented and copies provided to the design review team. A review period of 10 days will be given and comments will be provided back to the Contractor for resolution. After resolution of the comments a design review meeting will be held to go over the comment resolutions with the team for approval.

A design review report shall be prepared that documents the meeting minutes of the design review meeting and documents the approved comment resolutions. The design review report shall be provided to FDH after each of the design review meetings. 
During the first design review SNF Project shall complete an assessment of the air emissions that are defined in the latest K Basin Department of Health, Notice of Construction document, DOE/RL-96-101, "Radioactive Air Emissions Notice of Construction Fuel Removal for 105 KE Basin, February 1997. Any areas of deviation shall be identified.

The Contractor's technical staff, including, but not limited to, QA, safety, and drafting checker personnel, shall review all design drawings and technical documents, prior to submittal to the FDH for review. 


\subsection{DOCUMENTATION}

\subsection{CONTROL AND FORMAT}

All documents prepared by the contractor and turned over to the project shall be formatted to meet the requirements for release into the Hanford Site Document Control System per HNF-PRO-244, Engineering Data Transmittal Requirements. FDH shall supply the contractor with document number as requested.

Drawings will meet the requirements of HNF-PRO-709, Rev 1, Preparation and Control Standards for Engineering Drawings. FDH will provide the contractor with a block of numbers for drawings. Drawings will be as built prior to turn over to the project. A hard copy and electronic copy of drawing shall be turned over the CCS project manager at turnover. A professional engineer, licensed by the state of Washington, shall stamp drawings and specifications.

Submittals will be transferred to the project Design Authority for approval. The design authority will obtain additional reviews/approvals if required.

\subsection{DOCUMENT SUBMITTAL}

A list of submittals required and approval/concurrence levels are shown in Table 6.1. The Seller shall submit 9 copies of each deliverable. 


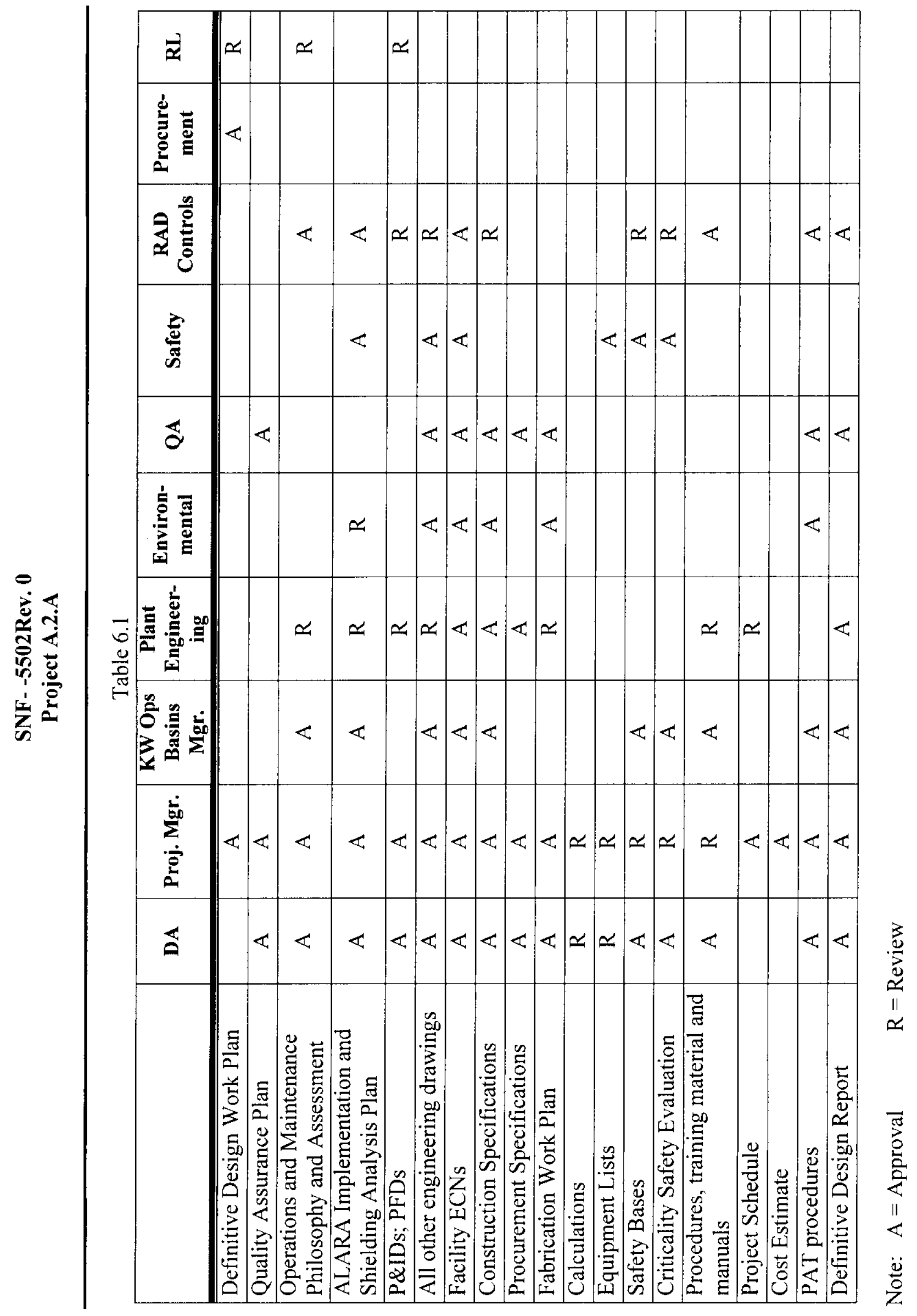




\subsection{CANISTER DISPOSAL}

The canisters cleaned and prepared for packaging, will be packaged and shipped to ERDF for final disposal. The canister will be packaged in an $8 \times 8 \times 20$-foot CONEX waste container transferred to Environmental Restoration Disposal Facility (ERDF) and grouted prior to burial. The CONEX boxes shall be purchased by the project and the tops modified to add access for the grouting process. Passive ventilation shall be maintained on the CONEX box during the loading activity.

The canisters shall be loaded in to the CONEX box using an operator aid.

The disposal criteria for ERDF is documented in BHI-00139 Rev 3, Environmental Restoration Disposal Facility Waste Acceptance Criteria.

The SNF Project is responsible for the following documentation to transfer waste to ERDF:

1. Sampling and analysis program

2. Waste profile, waste designation, and acceptance from ERDF personnel.

3. Obtain regulatory authority for disposal of waste at ERDF.

The SNF project management shall interface with the ERDF management and operation team to ensure that packaging, labeling, and handling of each shipment is in compliance with the appropriate waste compliance criteria. SNF Projects will prepare a waste management plan that includes the criteria for final disposition. 
SNF- -5502Rev. 0

Project A.2.A

\subsection{LABELING}

\subsection{IDENTIFICATION AND MARKING}

Identification and markings shall be legible, visible, and where necessary include cautionary labels to protect equipment and personnel. Items designed and manufactured per design drawings prepared by the Seller shall be marked in accordance with the AP EN-6-005, Engineering Component Identifier and Labeling Control. The SNF Project will supply numbers for all equipment and instrumentation.

\subsection{NAMEPLATE}

Stainless steel identification tags shall be permanently attached to each component of the CCS. Each tag shall be stamped with the unique component number assigned. In addition, each tag shall contain the Seller's name, equipment serial number, and date of manufacture. These required tags are in addition to any other tag that may be used by the vendor for his own purposes. 


\section{DISTRIBUTION SHEET}

\begin{tabular}{|c|c|c|c|c|c|}
\hline \multirow{2}{*}{$\begin{array}{l}\text { To: } \\
\text { Distribution }\end{array}$} & \multirow[t]{2}{*}{ From: } & \multirow{2}{*}{\multicolumn{2}{|c|}{ C. Farwick }} & \multicolumn{2}{|l|}{ Page 1 of 1} \\
\hline & & & & \multicolumn{2}{|c|}{ Date: November 22, 1999} \\
\hline \multirow{2}{*}{\multicolumn{4}{|c|}{$\begin{array}{l}\text { Project Title/Work Order } \\
\text { Debris Removal Subproject K West Canister Cleaning System, Project A2A - } \\
\text { SNF-5502, Rev. } 0\end{array}$}} & \multirow{2}{*}{\multicolumn{2}{|c|}{$\begin{array}{lr}\text { EDT No. } & 6 \\
\text { ECN No. } & \\
\end{array}$}} \\
\hline & & & & & \\
\hline Name & MSIN & $\begin{array}{l}\text { Text } \\
\text { With All } \\
\text { Attach. }\end{array}$ & $\begin{array}{l}\text { Text } \\
\text { Only }\end{array}$ & $\begin{array}{l}\text { Attach./ } \\
\text { Appendix } \\
\text { Only }\end{array}$ & $\begin{array}{c}\text { EDT/ECN } \\
\text { Only }\end{array}$ \\
\hline C. A. Bullock & $\mathrm{X} 3-68$ & $\mathrm{X}$ & & & \\
\hline D. E. Bullock & R3-86 & $\mathrm{X}$ & & & \\
\hline B. C. Cooper & X3-60 & & & & \\
\hline J. I. Diehl & $\mathrm{X} 3-80$ & & & & \\
\hline C. C. Farwick & $\mathrm{X} 3-85$ & $\mathrm{X}$ & & & \\
\hline M. J. Langevin & $\times 3-76$ & & & & \\
\hline J. D. Mathews & $\times 3-65$ & $\mathrm{X}$ & & & \\
\hline F. J. Muller & $X 3-85$ & $\mathrm{X}$ & & & \\
\hline S. H. Peck & R3-26 & & & & \\
\hline D. R. Precechtel & $\mathrm{X} 3-85$ & $\mathrm{X}$ & & & \\
\hline J. E. Turnbaugh & X3-79 & & & & \\
\hline K Basin Project Files A.13 & X3-85 & $\mathrm{X}$ & & & \\
\hline
\end{tabular}

